\title{
Human Parvovirus B19, Cytomegalovirus Infections and Thyroid Autoimmunity in Women with Recurrent First Trimester Abortion
}

\author{
Azza H. El-Salakawy ${ }^{1}$, Nahed H. Mohammed ${ }^{2}$, Olfat G. Shaker ${ }^{3}$ \\ and Ehab Ragaa Abdoul Raouf ${ }^{4}$
}

\author{
${ }^{1}$ Microbiology Department Faculty of Medicine ( Girls ), Al-Azhar University, \\ ${ }^{2}$ Obstetrics and Gynecology Department, Faculty of Medicine (Girls), Al-Azhar University, \\ ${ }^{3}$ Medical Biochemistry Department, Faculty of Medicine, Cairo University, \\ ${ }^{4}$ Human Genetic Department, National Research Center
}

\begin{abstract}
OBJECTIVE: The goal of this study was to modify and optimize the screening and diagnostic procedures of unexplained recurrent abortion. Antithyroid antibodies, parvovirus B19 (B19V) and cytomegalovirus (CMV) infections, which were usually overlooked in clinical practice of handling cases of recurrent abortion, were studied to evaluate their role in the pathogenesis of recurrent first trimester abortion. Also, we tried to elucidate the importance of detection of these agents and whether it should be routine prenatal investigations of women with unexplained recurrent abortion.

STUDY DESIGN: sixty women with unexplained recurrent first trimester abortion were the study group and thirty term healthy pregnant women, were selected as a control. Placental and fetal tissues were analyzed for B19V and CMV deoxyribonucleic acids using nested polymerase chain reaction (PCR) assay. Also sera were analyzed for T3, T4 and TSH levels, the presence of antithyroid antibodies (thyroglobulin and thyroid peroxidase), CMV specific IgM antibodies and parvovirus B19-DNA by dot blot hybridization assay.

RESULTS: Parvovirus B19-DNA was demonstrated in nearly one third of the aborted products $(19 / 60-31.67 \%)$ and $6.67 \%$ of the placentas of the control group, that represent highly significant difference $(\mathrm{P}<0.001)$. Whereas, serum samples of the two groups were negative for parvovirus B19 viral DNA by dot blot hybridization. Cytomegalovirus - DNA was demonstrated in 7/60 aborted tissues $(11.67 \%)$ and one placenta of the controls $(3.33 \%)$, that represent non significant changes $(\mathrm{P}>0.05)$. In contrast, only 5 aborting women $(8.33 \%)$ and a woman of the control group $(3.33 \%)$ were CMV-IgM seropositive, that also represent non significant changes $(P>0.05)$. Antithyroglobulin antibody levels were significantly higher in aborting women $(7 / 60)$ than control $(\mathrm{P}<0.05)$, whereas there was no significant changes in antithyroid peroxidase antibody levels between the two groups. Nine aborting women $(15 \%)$ were seropositive for one or both of the thyroid autoantibodies compared with two $(6.67 \%)$ of the control group, that represent non significant changes $(\mathrm{P}>0.05)$. We did not find any significant relation between thyroid autoimmunity and viral infections (B19V \& CMV) in women with unexplained recurrent first trimester miscarriage.

CONCLUSION: Parvovirus B19 infection was found to be an important pathogenic agent in recurrent first trimester abortion. It is essential to investigate for B19Vinfection among pregnant women with recurrent abortion. This significant finding demonstrates the usefulness of a sensitive molecular tool, PCR assay of viral DNA to aid in the diagnosis. However, testing for cytomegalovirus infection and antithyroid antibodies are not essential as routine prenatal investigations and should be restricted to certain patients with unexplained recurrent pregnancy loss.
\end{abstract}




\section{Human parvovirus B19, cytomegalovirus infections and thyroid}

\section{Introduction}

Recurrent pregnancy loss is an intriguing problem in obstetric practice. Over the last decade, many etiologic factors and several treatment regimens have been reported. However, there is no definite evidence for most causes of recurrent miscarriage and therapeutic interventions of any kind can be considered as merely empirical (Stirrat 1990).

Evidence supporting the autoim mune concept is now extensive. Triggering circumstances such as infection, endocrine, genetic, environmental, and cultural mechan isms, or ingestion of drugs as well as aging process appear to participate in the development of autoimmune diseases (Geva et al 1997). Abnormal autoantibody levels can result in clinical, subclinical, or preclinical autoimmune conditions. Muller et al (1999) reported that the presence of a large variety of autoantibodies were associated with repeated pregnancy loss. This association was first made with reference to lupus anticoagulant and other antiphospholipid antibodies (Lubbe and Liggins 1988). Thereafter, Stagnaro-Green et al (1990) were the first to describe the association between antithyroid antibodies and pregnancy loss.

On the other hand, many viral infections appear to be involved in the etiology of spontaneous abortion: cytomegalovirus, rubella, herpes simplex, mumps and Epstein Barr virus (Brown et al 1987; Stagno 1995). Although human cytomegalovirus (CMV) infection is the most common viral infections transmitted via the placenta (Baumann et al 2000), parvovirus B19 can also be transmitted from the infected mother to the fetus.
Therefore, spontaneous abortion, fetal anemia, nonimmune hydrops and stillbirth could result (Harger et al 1998).

The present study reports the results of our investigations in apparently healthy women with at least two or more unexplained first trimester pregnancy losses. These women were screened for certain factors that are not routinely investigated in clinical practice of handling a case of miscarriage, aiming at assessing its clinical importance and demonstrating whether it should be routine prenatal investigations in recurrent first trimester pregnancy losses. These women were screened for:

(1) Antithyroid autoantibodies in serum,

(2) Human parvovirus B19 (B19V) infection: viral DNA was detected in serum and aborted products.

(3) Cytomegalovirus (CMV) infection: specific- IgM antibodies in maternal serum and viral DNA in the placenta and products of conception.

Studying of these viral infections was selected because the infected patients are frequently asymptomatic or exhibited symptoms commonly associated with pregnancy, such as fatigue and joint pain. We tried to clarify whether there will be any association between viral infections (CMV and parvovirus B19) and presence of thyroid autoimmunity to determine their roles in the pathogenesis of recurrent first trimester pregnancy loss.

\section{Subjects and Methods}

One hundred pregnant women, the subjects of this study, were selected from the obstetrics and emergency departments of Al-Zahraa University hospital in the period from December 
1998 and December 1999. They were classified into two groups:

Group I : thirty term pregnant women ( $37-41$ weeks gestations) attending the delivery department with uncomplicated pregnancy and with no history of pregnancy loss (control group).

Group II: seventy pregnant women in the first trimester of pregnancy were admitted to the hospital with history of two or more recurrent abortions and presented with spontaneous abortion, missed or inevitable abortion, diagnosed by history, examinations and confirmed by ultrasound scanning (study group).

Most of the participants of the study group were selected from a larger pool of repeated aborters after women with obvious other causes of pregnancy loss had been excluded. Patients with significant uterine anomalies, uterine myomas, parental chromosomal abnormalities that were detected previously from peripheral blood, patients with possible luteal phase defect and autoimmune abnormalities among phospholipid antibodies were excluded. The majority of pregnancy losses in the final study group had not undergone prior chromosomal evaluation of products of conception. Chromosomal abnormalities in such pregnancy losses could therefore not be ruled out.

The patients age, parity, occupa tion, obstetric history, date of last menstrual period, and description of any symptoms (fever, rash, or arthralgias), or history of exposure to a child with erythema infectiosum were recorded. All women were subjected to the following:

A-Blood was drawn on admission and serum was stored at $-50^{\circ} \mathrm{C}$ for determination of:

1. TSH, T3 and T4 levels by ELISA

2. Thyroid autoantibodies: thyroid
Per -oxidase(TPO) and

thyroglobulin (TG)

3. determination of CMV specific IgM antibody, and parvovirus B19 DNA by dot blot hybridization assay.

$\underline{\boldsymbol{B}}$-The products of conceptions of the miscarried women and the placenta of the delivered women were collected and stored at $-70^{\circ} \mathrm{C}$ for nested PCR assay of:

1- $\quad$ Parvovirus B19 - DNA.
2-
Cytomegalovirus
(CMV)

DNA.

NB: we preferred to study B19V viral DNA in the aborted materials by PCR assay as Peters and Nicolaides (1990) demonstrated that IgM antibody determination is less sensitive than PCR assay and hence less useful tool for diagnosing intrauterine B19V infection. We also studied B19V viral DNA in the serum by hybridization technique.

\section{Laboratory evaluation:}

Active total T3 and thyroxin (T4) were determined by using enzyme linked immunosorbent assay method (Diagnostic System Laboratories , Inc, Texas , USA. Gruhn et al 1987). The procedure of ELISA followed the basic principle of enzyme immunoassay where there was competition between an unlabeled antigen and an enzyme labeled antigen for a fixed number of antibody binding sites. The amount of enzyme labeled antigen bound to the antibody was inversely proportional to the concentration of the unlabeled analyte present. Unbound materials were removed by decanting and washing the wells. The absorbance measured was inversely proportional to the concentration of $\mathrm{T} 3$ and $\mathrm{T} 4$ present in the serum. A set of $\mathrm{T} 3 \& \mathrm{~T} 4$ standards were used to plot a standard curve of absorbance versus T3\& T4 concentration and the unknowns can be 


\section{Human parvovirus B19, cytomegalovirus infections and thyroid}

calculated. The normal range for active T4 is defined as $4.5-11.3 \mu \mathrm{g} / \mathrm{dl}$ and for total T3 as $69-202 \mathrm{ng} / \mathrm{dl}$.

Thyroid peroxidase antibodies (TPO) were assayed using Quanta Litc TM TPO kit (Inova Diagnostics, INC,San Diego, calculated, Feldt- Rasmussen 1996). Purified human TPO antigen was bound to the wells of a polystyrene microwell plate under conditions that will prescure the antigen in its native state. Prediluted controls and diluted sera were added to bind to the immobilized antigen. Unbound sample was washed away and an enzyme labeled antihuman IgG antibody was added to each well. A second incubation allows the enzyme labeled to bind to any patient antibodies that had become attached to the microwell. After washing away any unbound enzyme conjugate, the remaining enzyme activity was measured by adding a chromogenic substrate and measuring of the color that developed. The assay can be evaluated by comparing the color that developed in the patient wells with the color in the central wells. Negative values range from 0-100 units, positive results are $>100$ units.

Thyroglobulin Antibodies by chemi luminescent EIA: Serum thyroglob ulin Antibodies were measured by IMMULITE Automated Analyzer (Spencer et al 1996). This method is a solid phase, two step chemiluminescent enzyme immunometric assay for use with the immulite for the quantitative measurement of antibodies against thyroglobulin. The solid phase, a ploystyrene bead enclosed within an Immulite test unit, is coated with highly purified thyroglobulin. The prediluted patient sample and the buffer matrix were simultaneously introduced into the test unit, and incubated for 30 minutes at $37^{\circ} \mathrm{C}$ with intermittent agitation. During this time, thyroglobulin autoanti -bodies in the sample bind to the thyroglobulin coated bead. The serum / buffer mixture was then removed by a centrifuge wash. An alkaline phosphatase-labeled antihuman IgG antibody was introduced, and the test unit was incubated for another 30-min. cycle. The unbound enzyme conjugate was removed by a centrifugal wash, after which substrate was added, and the test unit was incubated for a further 10 min. the chemiluminescent substrate, a phosphate ester of adamantyl dioxetane, under hydrolysis in the presence of alkaline phosphate to yield a stable intermediate. The continuo production of this intermediate resulted in the sustained emission of light, thus improving precision by providing a window for multiple readings. The bound enzyme conjugate and thus also the photon output, as measured by the luminometer was proportional to the concentration of thyroglobulin autoantibodies in the sample. The detection limits of the assays defined as the concentration two standard deviations above the response at zero dose, is approximately $3 \mathrm{IU} / \mathrm{ml}$.

N. B: Elevated levels of antibodies to thyroid peroxidase (TPO antibodies) occurred more frequently than high anti-thyroglobulin levels in autoimmune thyroid disease, however, antithyroglobulin determination therefore did not seem to add to the diagnostic information provided by anti- TPO results.

\section{Cytomegalovirus IgM antibodies by chemiluminescent EIA:}

Qualitative detection of IgM antibodies to cytomegalovirus (CMV) in human serum by Immulite Automated Analyser Immulite CMV IgM is a solid phase, two step chemiluminescent enzyme immunoassay (Baltz and Searcy 1994). The solid phase, a polystyrene bead enclosed within an Immulite tests unite, 
is coated with partially purified CMV antigen. The procedure of detection is the same as that of antithyroglobulin. A qualitative result was obtained by comparing the patient result to an established cut off. The volume of sample required was $10 \mu \mathrm{l}$ of the prediluted patient samples.

\section{Dot blot hybridization assay of parvovirus B19 DNA in sera:}

The assay was performed according to Yoto et al (1995). In brief, $20 \mu \mathrm{l}$ of each serum mixed with $180 \mu \mathrm{l}$ of distilled water, were filtered with manifold apparatus (Biometra,) onto a treated nylon membrane (genescreen, BRL, USA). After the samples were filtered the nylon membrane was air dried and baked for 2 hours under a vacuum at $80^{\circ} \mathrm{C}$. The specimens on the filters were then alkali denatured, neutralized, treated with proteinase $\mathrm{K}$ and washed in $2 \times \mathrm{SSC}$ buffer $(0.3 \mathrm{M}$ $\mathrm{NaCl}$ plus $0.03 \mathrm{M}$ sodium citrate; $\mathrm{pH}$ 7.0). After prehybridization at $65^{\circ} \mathrm{C}$ for 2 hours in mixture $(5 \times \mathrm{SSC}, 250 \mu \mathrm{g}$ of sheared denatured salmon sperm DNA per $\mathrm{ml}, 25 \mathrm{mM} \mathrm{NaPO} 4(\mathrm{pH} 6.5), 5 \times$ Denhardt's and $50 \%$ formamide). The prehybridization mixture was removed and replaced with hybridization mixture containing $1 \mu \mathrm{g}$ of biotin- labeled DNA probe 5'- Biotin-labeled AAACTG TC TGGAAAATGTACAAGTTACAGAG

TTAGCACTA-3'. The reaction was allowed to proceed at $65^{\circ} \mathrm{C}$ for 16 hours. Then the membrane was washed in 250 $\mathrm{ml}$ of $2 \times \mathrm{SSC}-0.1 \%$ (wt/vol) SDS for 5 min at room temperature (RT); $250 \mathrm{ml}$ of $0.2 \times \mathrm{SSC}-0.1 \%$ SDS for $5 \mathrm{~min}$ at RT; and $250 \mathrm{ml}$ of $0.16 \times$ SSC- $0.1 \%$ SDS for $15 \mathrm{~min}$ at $50^{\circ} \mathrm{C}$ twice. For colourimetric DNA detection, filter was washed for 1 $\min$ in $0.1 \mathrm{M}$ Tris- $\mathrm{HCl}(\mathrm{pH} 7.5)-0.15$ $\mathrm{M} \mathrm{NaCl}$ and non specific binding sites were blocked by immersion in a $3 \%$ solution of bovine serum albumin in the same buffer for $40 \mathrm{~min}$ at $65^{\circ} \mathrm{C}$.
Streptavidin- peroxidase conjugate $(1 \mu \mathrm{g} / \mathrm{ml}$ in the same buffer) was added for $10 \mathrm{~min}$ with gentle agitation. The filter was washed twice in $250 \mathrm{ml}$ of 0.1 M Tris $\mathrm{HCl}$ (pH7.5)-0.15M NaCl for 15 min at RT. Filter was sealed in polypropylene bag with freshly prep ared substrate solution containing $6 \mathrm{mg}$ of 3,3 diaminobenzidine tetrahyd rochloride in $10 \mathrm{ml}$ of $0.05 \mathrm{M}$ Tris- $\mathrm{HCl}$ $\mathrm{pH} 7.6$ and $0.1 \mathrm{ml}$ of $3 \%$ hydrogen peroxide. Development of a brown colour with +ve reference was allowed to proceed for 10-60 min in dark, then terminated by washing the filter in 20 $\mathrm{mM}$ Tris $\mathrm{HCl}(\mathrm{pH} 7.5)$ and $0.5 \mathrm{mM}$ disodium EDTA, then air dried.

\section{Detection of Parvovirus B19 - DNA in tissues by nested PCR:}

DNA was extracted from aborted products and placental tissues by using DNA high pure PCR template preparation kit (Boehringer mannheim, Germany) as instructed by manufacture.

Nested PCR assay: the nested PCR was performed according to Zerbini et al (1996). In brief, $7 \mu 1$ of extracted DNA was added to PCR mix for a total volume of $50 \mu$ l containing $5 \mu 1$ of $10 \mathrm{x}$ PCR buffer, $3 \mu \mathrm{l}$ of $25 \mathrm{mM} \mathrm{MgCl} 2,2.5$ $\mathrm{U}$ of Taq DNA polymerase (Promega, UK) , $200 \mu \mathrm{M}$ each deoxynucleotide triphosphate ( Stratagen) and 300ng of each primer. After an initial denaturation step of $5 \mathrm{~min}$ at $95^{\circ} \mathrm{C}$, the first- round PCR amplification was performed. Then $3 \mu \mathrm{l}$ first- round product was transferred to a second 50$\mu l$ PCR mix. The second - round reaction mix contained the same constituents as the first- round mix, but $300 \mathrm{ng}$ of each second primer was substituted for each first primer.

The oligonucleotide primers used in the first round of amplification were 5'CTTTAGGTATAGCCAACTGG-3' and 5'-ACACTGAGTTTACTAGT GGC3 ', yielding a product of $1,112 \mathrm{bp}$. 


\section{Human parvovirus B19, cytomegalovirus infections and thyroid}

Second - round PCR was performed with primers 5'CAAAAGCATGTGGAGTG AGG-3' and 5 '- CCTTATAATGG TGCTCTGGG -3 'to give a product of 104 bp. Thirty - five cycles of both first and second - round amplification were performed under the following condi tions : $95^{\circ} \mathrm{C}$ for $1 \mathrm{~min}, 55{ }^{\circ} \mathrm{C}$ for 1.5 min, and $72^{\circ} \mathrm{C}$ for $1 \mathrm{~min}$, then final extension at $72^{\circ} \mathrm{C}$ for $7 \mathrm{~min}$ for one cycle. Ten - microliter samples of second -round PCR products were then analyzed by electrophoresis in a $2 \%$ agarose gel. Bands were visualized by ethidium bromide staining.

\section{Detection of CMV - DNA in tissues by nested PCR:}

Two pairs of primers were used according to Krajden et al, (1996). The outer primer set consisted of upstream primer JC, 5'- CATAATCTCATCA GGGGAGC- 3', and downstream primer JD, 5'-TTGGGCTAACTATGC AGAGC- 3', which generated a 305-bp. The inner primer set consisted of upstream primer JB,5'-GAAGGCTGA GTTCTTGGTAA-3', and downstream primer JA, 5'-AGCTGCATGATGTGA GCAAG-3'. First PCR was performed by adding $5 \mu \mathrm{l}$ of $10 \mathrm{x}$ reaction buffer containing $10 \mathrm{mM}$ Tris, $50 \mathrm{mM} \mathrm{KCl}$ $(\mathrm{pH} 8.3) ; 3 \mu \mathrm{l}$ of $25 \mathrm{mM} \mathrm{MgCl} 2$; deoxynucleoside triphospate (dNTP) mix containing $10 \mathrm{mM}$ (each) dATP, dCTP, dGTP and dTTP; 50 pmol of each primer; $2 \mathrm{U}$ of Taq polymerase (Promega) and $7 \mu \mathrm{l}$ of sample DNA (total volume, $50 \mu \mathrm{l}$ ). Samples were denatured at $95^{\circ} \mathrm{C}$ for $5 \mathrm{~min}$ and subjected to 30 amplification cycles as followed: denaturation for $1 \mathrm{~min}$ at $94^{\circ} \mathrm{C}$, annealing for $1 \mathrm{~min}$ at $55^{\circ} \mathrm{C}$, and extension for $1.5 \mathrm{~min}$ at $72^{\circ} \mathrm{C}$, with a final extension for $7 \mathrm{~min}$ at $72^{\circ} \mathrm{C}$ in a Perkin-Elmer 4800 thermocycler. Three microliters of PCR products from the first PCR was reamplified by using the same amplification protocol with 50 pmol of each inner primers. PCR products of 168 - bp were detected by $2 \%$ agarose gel electrophoresis. Multiple negative controls, aerosolresistant- tips, and separate processing areas were used to minimize the risk of amplicon contamination.

Statistical analysis: Demographic, medical and laboratory information were entered concurrently into a custom- designed database. Descriptive statistics were calculated using student's t test, the $\mathrm{X}^{2}$ test, crosstab / Chi-square tests. The results were expressed as mean value $\pm \mathrm{SD}$. P value $<0.05$ and $<0.01$ were considered significant.

\section{Results:}

The results of this study were recorded in six tables and three figures. Ten cases (10/70) were excluded from the aborted group because of hemolysis of the blood samples of some and autolysis of tissue specimens of others. Therefore only 60 miscarried women were studied in group II. There was no history of risk factors for $\mathrm{CMV}$ or $\mathrm{B} 19 \mathrm{~V}$ infections in pregnant women of this study and we suspected exposure to their own children at home may be the only risk factor, as most infected children are asymptomatic. Further, we could not demonstrate a significantly greater risk by any maternal occupation. Table (1) showed that women in both groups were matched in maternal age.

The results of thyroid autoantibodies were recorded in tables (2) and (3). Whereas thyroglobulin antibodies levels were significantly higher in the aborted women than control $(p<0.05)$, there was no significant changes in the thyroid peroxidase antibodies levels between the two groups $(\mathrm{P}>0.05)$. Summation of the results of both thyroid antibodies were not significantly changed between the two 
groups. Patients were determined to be euthyroid by demonstrating normal levels of thyroid-stimulating hormone (TSH), T4 and T3. Analysis of the thyroid hormonal levels revealed that 56 women were euthyroid (mean T4 $=4.85$ $\mu \mathrm{g} / \mathrm{dL}$ and mean T3. $=163.691 \mathrm{ng} / \mathrm{dL}$ ), four women were hyperthyroid and none were hypothyroid in the recurrent miscarried group. Whereas in the control group only one woman was hyperthyroid and 29 were euthyroid (mean T4 $=6.44 \mu / \mathrm{dL}$ and mean $\mathrm{T} 3=$ $150.02 \mathrm{ng} / \mathrm{dL})$. These results were not statistically significant.

Table (4) and figure (1) showed that detection of parvovirus DNA was significantly higher in the aborted tissues than in the placentas of the control group $(\mathrm{P}<0.01)$. Of the women infected by B19V no one reported recent signs or symptoms consistent with parvovirus infection (fever, rash, or arthralgias), and none recalled exposure to a child with erythema infectiosum and ultrasound scans showed no evidence of hydrops fetalis.

Table (5) showed the results of serum CMV IgM and tissues CMVDNA. Figure (2) demonstrated CMV viral DNA by PCR assay.

Table (6) showed that, among the aborted women, DNA amplification by PCR for parvovirus B19 was strongly positive in 19 women $(31.67 \%)(\mathrm{P}<$ $0.01), 5 / 29(26.32 \%)$ of these women were seropositive for thyroid antibodies, $2(10.53 \%)$ women were seropositive for CMV IgM and only one (5.26\%) demonstrated CMV - DNA in the products of conceptions. This represents statistically non-significant changes $(\mathrm{P}$ $>0.05$ ) and revealed that there was no relationship between viral infections and thyroid autoimmunity in the studied groups.

figure (3) is a chart demonstrating the percentage of parvovirus B19 and CMV viral infections and antithyroid antibodies seropositive in both groups.

Table (1) Clinical characteristics of the studied women [mean \pm SD (range)].

\begin{tabular}{|l|l|l|}
\hline \multicolumn{1}{|c|}{ Items } & Control group (I) & Study group (II) \\
\hline Age(Years) & $31 \pm 3.1(25-41)$ & $32 \pm 2.1(27-42)$ \\
$* \mathrm{GA}(\mathrm{W})$ at collection & $39 \pm 1.2(37-41)$ & $12 \pm 7.8(7-20)$ \\
No. of prior abortions & 0 & $3.6 \pm 1.1(2-8)$ \\
No. of primary aborters & 0 & 50 \\
No.of Secondary aborters & 0 & 10 \\
\hline
\end{tabular}

* $\mathrm{GA}=$ gestational age in weeks 
Human parvovirus B19, cytomegalovirus infections and thyroid

Table (2) Thyroid autoantibodies in the studied women .

\begin{tabular}{|c|c|c|c|c|c|}
\hline \multirow[t]{2}{*}{ Antihyroid antibodies } & \multicolumn{2}{|c|}{ Control group $(n=30)$} & \multicolumn{2}{|c|}{ Study group $(n=60)$} & \multirow[t]{2}{*}{$\mathrm{P}$ value } \\
\hline & $+\mathrm{ve}$ & $-v e$ & $+\mathrm{ve}$ & -ve & \\
\hline $\begin{array}{l}\text { TG IU } / \mathrm{ml}(+\mathrm{ve}> \\
40 \mathrm{IU} / \mathrm{ml}) \\
\text { Number of cases } \\
\text { Mean } \pm \text { SD } \\
\text { Range }\end{array}$ & $\begin{array}{l}0 \\
-\end{array}$ & $\begin{array}{l}30 \\
-\end{array}$ & $\begin{array}{l}7 \\
64.92 \pm 50.01 \\
44-150\end{array}$ & $\begin{array}{l}53 \\
21.83 \pm 11.5 \\
11-33\end{array}$ & $\begin{array}{c}<0.05 \\
S\end{array}$ \\
\hline $\begin{array}{l}\text { TPO units (+ve > } \\
100 \text { units } / \mathbf{m L}) \\
\text { Number of cases } \\
\text { Mean } \pm \text { SD } \\
\text { Range }\end{array}$ & $\begin{array}{l}2 \\
228.82 \pm 150.32 \\
110.2-346.2\end{array}$ & $\begin{array}{l}28 \\
31.45 \pm 15.93 \\
1.3-61\end{array}$ & $\begin{array}{l}2 \\
400.2 \pm 196.52 \\
132-667\end{array}$ & $\begin{array}{l}58 \\
17.88 \pm 10.5 \\
6.5-75.5\end{array}$ & NS \\
\hline
\end{tabular}

TG $=$ Thyroglobulin antibodies

$+\mathrm{ve}=$ antibodies positive

TPO $=$ Thyroid peroxidase antibodies -ve $=$ antibodies negative

$\mathrm{S}=$ significant

NS = non significant

Table(3) Antithyroid antibodies (TG +TPO) in the studied women.

\begin{tabular}{|c|c|c|}
\hline Groups & $\begin{array}{l}\text { Antibodies-Positive } \\
\text { group }\end{array}$ & $\begin{array}{l}\text { Antibodies-Negative } \\
\text { group }\end{array}$ \\
\hline $\begin{array}{l}\text { Control group }(\mathbf{n}=\mathbf{3 0}) \\
\text { Number } \% \\
\text { Age (year mean } \pm S D) \\
N \text { of prior abortions }(\text { mean } \pm S D) \\
\text { Study aroup }(\mathbf{n}=60)\end{array}$ & $\begin{array}{ll}2 & 6.67 \% \\
32 \pm 3.1 & \\
0 & \end{array}$ & $\begin{array}{l}28 \\
30 \pm 3.1 \\
0\end{array}$ \\
\hline $\begin{array}{l}\text { Number \% } \\
\text { Age (year mean } \pm S D) \\
N \text { of prior abortions }(\text { mean } \pm S D)\end{array}$ & $\begin{array}{ll}9 & 15 \% \\
33 \pm 2.9 & \\
4.5 \pm 1.6 & \end{array}$ & $\begin{array}{l}51 \\
34 \pm 3.4 \\
3.6 \pm 0.93\end{array}$ \\
\hline
\end{tabular}

Table (4) Parvovirus B19 -DNA in sera; placentas; and products of conceptions of the studied groups

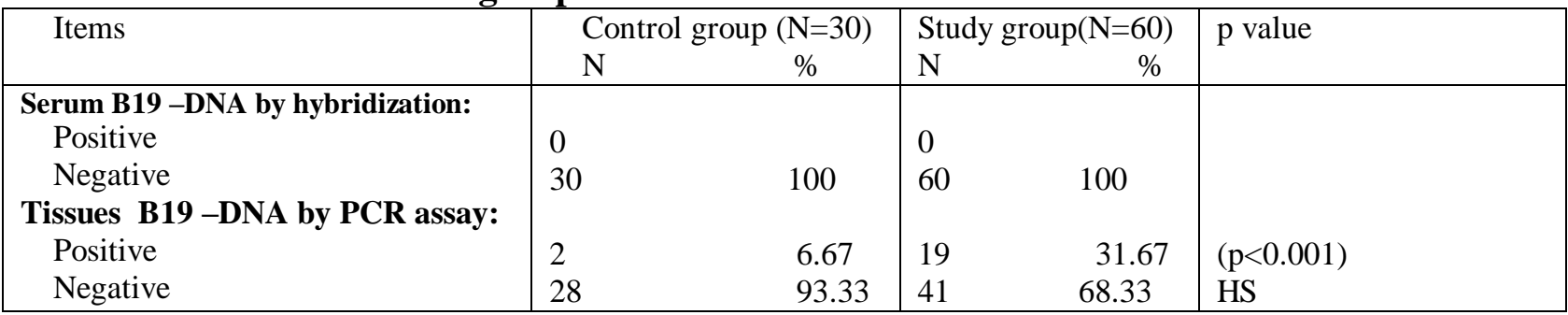

$\mathrm{HS}=$ highly significant 
Azza H. El-Salakawy et al

Table (5) Repeated miscarriage versus normal delivery: Serum CMV specific IgM antibodies and CMV - DNA in the products of conceptions and placentas by PCR.

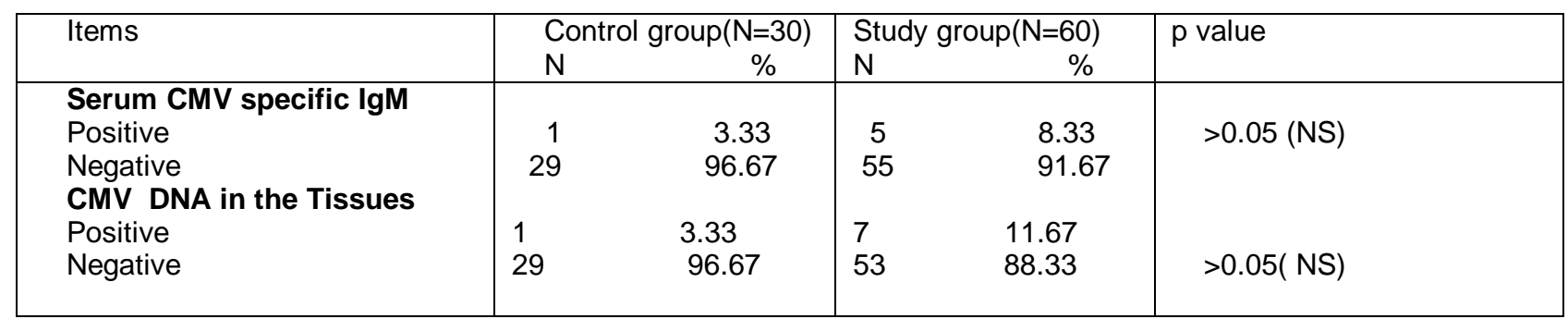

Table (6) The frequency of CMV infection and thyroid autoantibodies in women with evidence of B19V infection by PCR

\begin{tabular}{|c|c|c|c|c|c|c|c|c|}
\hline \multirow[b]{2}{*}{ Items } & \multicolumn{3}{|c|}{$\frac{\text { Control group }(\mathrm{n}=30)}{\text { Placenta } \mathrm{B} 19 \mathrm{~V} \text { PCR }}$} & \multicolumn{4}{|c|}{$\frac{\text { Study group }(\mathrm{n}=60)}{\text { Products of conception B19V PCR }}$} & \multirow[t]{2}{*}{$\mathrm{p}$ value } \\
\hline & $*+\mathrm{ve}(\mathrm{n}=2)$ & - ve ( & & & $n=19)$ & - ve & 41) & \\
\hline $\begin{array}{c}\begin{array}{c}+\mathrm{ve} \\
-\mathrm{ve}\end{array} \\
\frac{\text { Tissues CMV PCR: }}{+\mathrm{ve}} \\
-\mathrm{ve} \\
\frac{\text { Thyroid }}{\text { autoantibodies: }} \\
\begin{array}{c}+\mathrm{ve} \\
-\mathrm{ve}\end{array} \\
\text { total }\end{array}$ & $\begin{array}{ll}0 & \\
2 & 100 \% \\
2 & 6.67 \%\end{array}$ & $\begin{array}{l}2 \\
26 \\
28\end{array}$ & $\begin{array}{r}3.56 \% \\
96.44 \% \\
\\
3 . .56 \% \\
96.44 \%\end{array}$ & $\begin{array}{l}2 \\
17 \\
\\
\\
1 \\
18\end{array}$ & $\begin{array}{c}10.53 \% \\
89.47 \% \\
\\
5.26 \% \\
94.74 \%\end{array}$ & $\begin{array}{l}4 \\
37 \\
41\end{array}$ & $\begin{array}{c}7.32 \% \\
92.68 \% \\
\\
14.63 \% \\
85.37 \%\end{array}$ & NS \\
\hline
\end{tabular}

$*+\mathrm{ve}=$ women demonstrated B19 V DNA in the placenta or products of conceptions

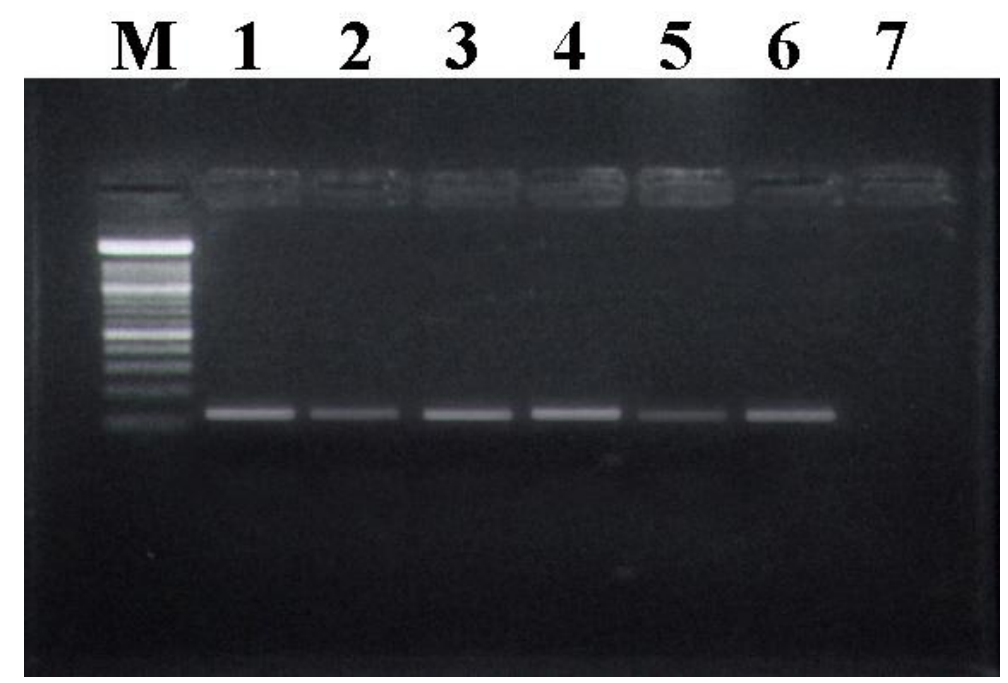

Fig. (1): Agarose gel electrophoresis of PCR amplification products of parvovirus B19 DNA, M : 100 bp DNA molecular size marker, positive samples (104 bp),(lanes:16), negative control, lane (7). 


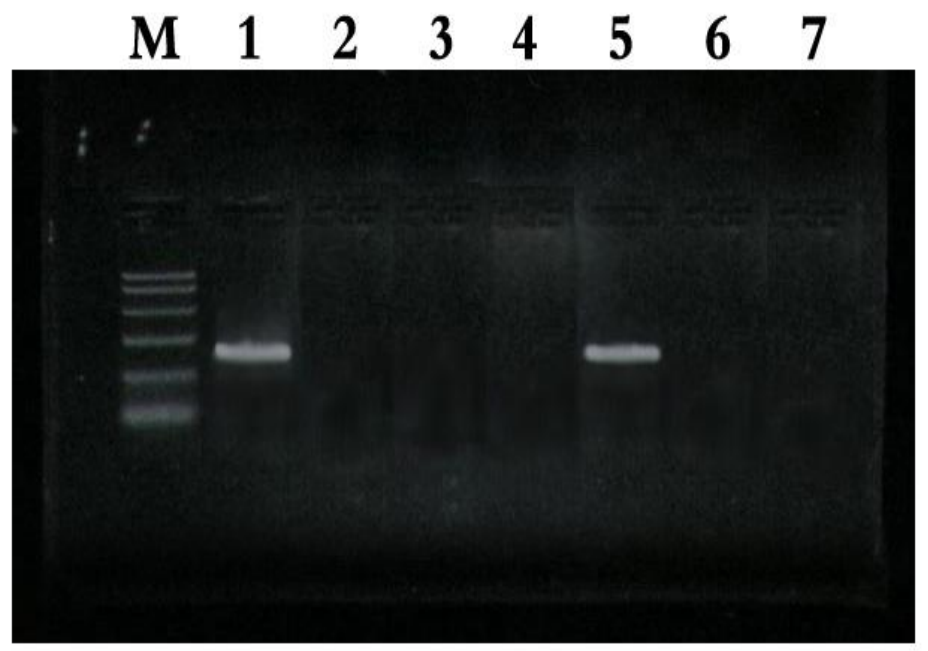

Fig.(2): Agarose gel electrophoresis of PCR amplification products of Cytomegalovirus DNA, M : DNA molecular size 50 bp marker, positive samples (168 bp)(lanes: 1,5), lane (2), negative control, lanes $(3,4,6,7)$ were negative samples.

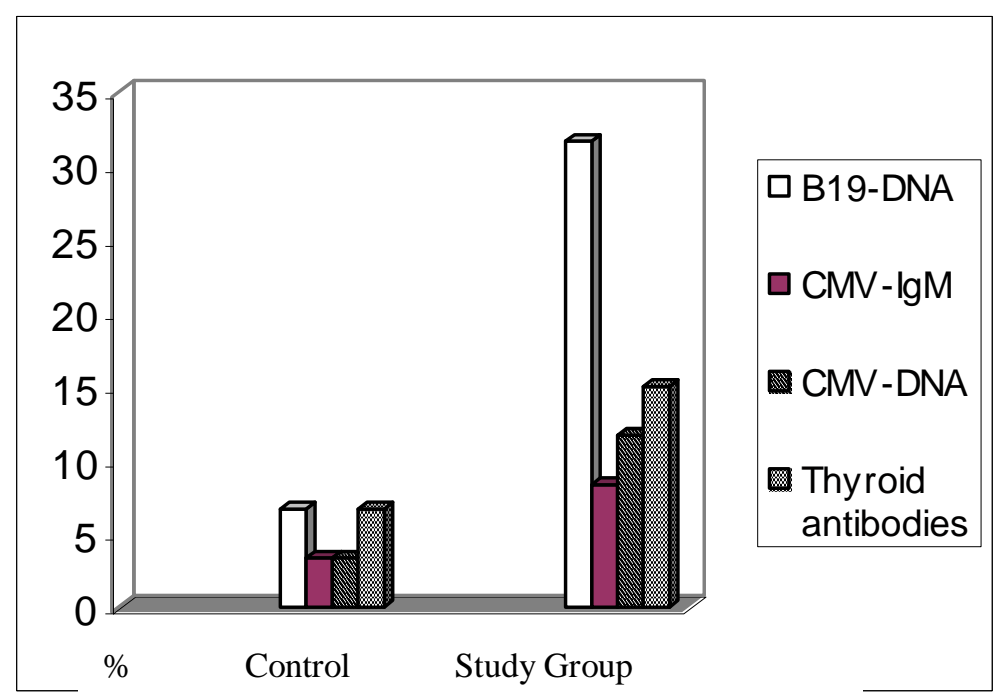

Figure (3) The percentage of positive parvovirus B19 - DNA and CMV - DNA in tissues, CMV-IgM seropositive and antithyroid antibodies seropositive results in the studied women .

\section{Discussion}

Antithyroid antibodies are known to occur in apparently healthy populations and are more frequently observed in women during their reproductive years. One or both of the antithyroid antibodies (thyroid peroxidase and thyroglobulin) were demonstrated in $15 \%$ of the patients with recurrent spontaneous abortions compared with $2 \%$ of the control group. This result is not statistically significant. Whereas, $85 \%$ of the miscarried women in the present study did not demonstrate thyroid 
antibodies in their sera, $2 \%$ of the control group, that were antithyroid seropositive, had delivered healthy babies. Inspite only thyroglobulin levels were significantly higher in women with recurrent abortion than control. Stagnaro-Green et al (1990) reported that the individual levels of antithyroid peroxidase and antithyroglobulin autoantibodies were similarly related to the increased rate of miscarriage, with no evidence of autoantibody specificity.

On the contrary, Pratt et al. (1993) reported a higher incidence of antithyroid antibodies in women with a history of three or more consecutive pregnancy losses as compared with a control population (31\% versus $19 \%$ ). Singh et al (1995) also found that thyroid antibodies might be useful markers for identifying women at risk of clinical miscarriage. In the antibody-positive group they found that there was $32 \%$ clinical miscarriage rate in comparison to $16 \%$ in the antibody-negative group. They reported a strong association between antithyroid autoantibodies and spontaneous abortion.

Stagnaro - Green et al (1992) suppo -rted the concept that the basic immun -ologic defect in autoimmune diseases probably lies at the Tlymphocyte level. Pratt et al. (1993) supported the hypothesis that antithyroid antibodies may serve as peripheral markers for abnormal T-cell function that, in turn, may be responsible for pregnancy loss and demonstrated that detection of thyroid antibodies before conception carries an increased risk of pregnancy loss. It is then tempting to speculate that abnormal T-lymphocyte function, and not abnormal autoantibodies per se, is responsible for pregnancy loss. Under such a concept, they reported that organ-specific autoantibody abnorma lities, such as thyroid antibodies and non organ-specific autoantibodies, can be expected to have similar prognostic significance for impending pregnancy loss. Muller et al (1999) concluded that successful treatment of autoantibody-associated pregnancy loss should concentrate on attempts to modulate $\mathrm{T}$-cell function rather than the customary treatment options of antibody suppression and/or modulation of antibody effects.

Whereas B19 viral DNA was detected in fetal and placental tissues, by PCR, nearly in one third of the miscarried women and $6.67 \%$ of the control group, viral DNA was not detected directly in sera by dot blot hybridization in the two groups. This finding could be explained on the basis of less sensitivity of hybridization technique than PCR. On the other hand it may be attributed to less viral concentrations in peripheral blood. In fact, the nested PCR can disclose a single copy of B19 -DNA (Zakryewska et al, 1992), while dot blot hybridization technique have been shown to detect more than $10^{4}$ viral particles (Musiani et al, 1993). In the present study, the total number of tested sera was 90 samples which are considered less than that tested by Mori et al (1989) and Yoto et al (1995) who used hybridization technique for detection of B19 -DNA in the serum and found positive reactions in 48/4895 (0.9\%) and 15/7969 (0.2\%) respectively. Polymerase chain reactionbased assay was shown to be a more sensitive and accurate means of diagnosing $\mathrm{B} 19 \mathrm{~V}$ infection. The problem with polymerase chain reaction-based methods is not their lack of sensitivity but rather their extraordinary sensitivity.

Gratacos et al (1995) and Harger et al (1998) reported that the overall 


\section{Human parvovirus B19, cytomegalovirus infections and thyroid}

incidence of fetal loss linked to parvovirus B19 infection was $1.66 \%$ and $8.3 \%$ of B19- IgM-positive pregnant women respectively.The figures considerably lower than that reported in the present study. Gratecos et al (1995) findings provided evidence that parvovirus infection during pregnancy is a rare cause of fetal morbidity and mortality and they suggested that adverse outcomes are infrequent even in a population with a high incidence of infection. On the contrary Jordan (1996) reported that B19V infection of pregnant women have been associated with poor fetal outcomes, including fetal anemia, nonimmune hydrops, spontaneous abortion, and stillbirth. However, transplacental transmission rate of B19V has been estimated to be about $33 \%$, indicating that this virus could be more fetotropic and fetotoxic than either rubella or cytomegalovirus. Therefore, it is important for the physician to have accurate clinical data regarding the immune status of a pregnant woman when an exposure to or infection by B19V is suspected. Adults may have no clinical evidence of disease even though serologic studies, IgM and IgG antibodies would indicate recent infection. Jordan (2000) concluded that fetuses should be monitored for up to 14 weeks after maternal exposure to B19V infection.

Cytomegalovirus infection during pregnancy is far more complex than other infections, such as rubella and toxoplasmosis, which occur only with primary infections, because of the ability of this virus to become reactivated frequently during the childbearing years and to be transmitted to the fetus inspite of maternal immunity (Stagno 1995). Of all investigate miscarrying women in our study the percentage of seropositive and seronegative mothers did not differ significantly. This result was in agreement with that of Stagno (1995).

Early diagnosis of CMV leads to dramatically better prognosis; a hypothesis that has to be examined (Stagno 1995). However, this still leaves the problem that there is no specific and effective therapy for congenital CMV infection that can be administered during pregnancy. This leads to the phenomenon that most clinicians do not screen at all. In order to overcome these problems a step-wise screening of CMV to avoid a false positive result is needed. This is necessary because a mother expressing CMV-IgM does not necessarily transmit the virus to the child as observed in our results. Positive IgM anti-CMV results may furthermore be false-reactions with other substances, such as rheumatoid factor, or nonspecific reactions. Baumann et al(2000) reported a low specificity of $\operatorname{IgM}$ anti-CMV test. However, in a screening program false positive results can be rather accepted than false negative results, since the positive serological result has to be confirmed by a specific and sensitive methods as virus isolation by shell vial cell culture assay and by PCR for CMV - DNA detection ( Revello et al, 1999). In order to verify whether the serological screening of mothers in the present study really detected transplacental transmission and hence detection of congenitally infected fetuses, CMV specific IgM levels were compared with screening for CMV DNA in fetal and placental tissues. We found only two out of the 5-CMV - IgM positive miscarried women demonstrated viral DNA in the products of conceptions. So that not all CMV IgM seropositive miscarried women transmitted the virus to their fetuses. Although the etiology of autoimmune 
diseases is unknown, there are some clues as regards the predisposing factors: genetic factors, certain HLA class I and II alleles or invading microorganisms may be involved in the early stage of the disease and T-cells are often involved in the etiology and pathogenic process, in fact the etiology is likely to be multifactorial ( Peakman and Vergani, 1997). In the current study we did not find any significant association between thyroid autoimmunity and viral infections in women with unexplained recurrent miscarriage.

We concluded that parvovirus B19 infection represents nearly one third of the etiology of unexplained recurrent abortions in the present study. Therefore it should be included in routine screening of cases of recurrent abortion. However, the detection of cytomegalovirus infection in aborted women of the present study does not support a role for CMV infection as a major abortion related factor. Thyroid autoimmunity might serve an independent pathogenic risk factor for repeated pregnancy loss. Testing for IgM anti-cytomegalovirus and antithyroid antibodies should be restricted to certain patients with unexplained recurrent pregnancy loss.

We recommend using PCR assay of placenta or fetal blood/tissue samples for screening of potential $\mathrm{B} 19 \mathrm{~V}$ or CMV infections in utero.

\section{REFERENCES}

Baltz ML and Searcy RL: Clinical significance and advanced serologic diagnosis of TORCH infections. Am. Clin Lab 1994, April: 18- 23.

Baumann HG, Genser B, Danda M, Engele H, Rosegger H, Folsch B, Maurer U, Lackner $\mathrm{H}$, and Truschnig-Wilders M: Screening and diagnosis of congenital cytomegalovirus infection : A 5-y study. Scand J. infect Dis, 2000; 32:137-142

Brown ZA, Vontver LA and Benatti J: Effects on infants of genital herpes during pregnancy. N Engl J.Med; 1987, 317: 1246- 1251.

Feldt- Rasmussen U: Analytical and clinical performance goals for testing autoantibodies to thyroperoxidase, thyroglobulin, and thyroprotein receptor. Clinical Chemistry, 1996; 42: 160-169.

Geva E, Amit A, Geva LL, and Lessing JB: Autoimmunity and reproduction. Fertil and Steril 1997;67, 4 :599-611.

Gratacos E, Torres PJ, Vidal J, Antolin E, Costa J, Jimenez de Anta MT, Cararach V, Alonso PL and Fortuny A: The incidence of human parvovirus B19 infection during pregnancy and its impact on perinatal outcome.J Infect Dis 1995; 171:13601363.

Gruhn J G, Borsano C P, and Kumar Y : The development of test of thyroid function. Arch Path Lab Med 1987; 111: 84- 100.

Harger J.H, Adler S, Koch W and Harger G.F: Prospective evaluation of 618 pregnant women exposed to Parvovirus B19 : Risk and symptoms. Obstet Gynecol 1998; 91:413-20.

Jordan JA: Identification of human parvovirus B19 infection in idiopathic non immune hydrops fetalis.Am J Obestet Gynecol 1996; 174:37-42.

Jordan JA: Comparison of baculovirus - based VP2 enzyme immunoassay ( EIA) to an Escherichia coli - based VP1 EIA for detection of human parvovirus B19 Immunoglobulin $\mathrm{M}$ and Immunoglobulin $G$ in sera of pregnant women . J Clin Microbiol 2000; 4 : 1472-1475.

Krajden M, Shankaran P, Bourke C and Lau W: Detection of cytomegal ovirus in blood donors by PCR using 
the digene SHARP signal system assay: effects of sample preparation and detection methodology. J. Clin. Microbiol, 1996; 34: 29-33.

Mori J ,Field AM, Clewley JP and Cohen BJ: Dot blot hybridzation assay of B19 virus DNA in clinical specimems. J.Clin. Microbiol. 1989;27:459-464.

Lubbe WF and Liggins GC: Role of the lupus anticoagulant and autoimmunity in recurrent pregnancy loss. Semin Reprod Endocrinol 1988; 6:181-90.

Muller AF, Verhoeff A, Mantel MJ and Berghout A: Thyroid autoimmunity and abortion : a prospective study in women undergoing in vitro fertilization. Fertil and Steril 1999; 71: 30-34.

Musiani M, Azzi A,Zerbini $M$ and Gibillini D: Nested polymerase chain reaction assay for detection of B19 parvovirus DNA in human immunodeficiency virus patients. J. Med. Virol. 1993; 40:157-160.

Peakman $M$. and Vergani D: Endocrine autoimmune disease In : Basic and clinical immunology Churchill Livingstone . 1997; p183-198.

Peters $\mathbf{M}$; and Nicolaides $\mathrm{K}$ : Cordocentesis for the diagnosis and treatment of human fetal parvovirus infection.Obstet Gynecol 1990; 75: 501504.

Pratt DE, Kaberlein G Dudkiewicz A, Karande V, Gleicher N. The association of antithyroid antibodies in euthyroid nonpregnancy with recurrent first trimester abortions in the next pregnancy . Fertil Steril 1993; 60 : $10001-10005$

Revello MG, Zavatton M, Sarasin A, Baldamti F, De Julio C, De Giuli L, Nicolni $U$ and Gerna G: Prenatal diagnostic and prognostic value of human cytomegalovirus load and $\operatorname{IgM}$ antibody response in blood of congenitally infected fetuses. The
Journal of infectious diseases 1999; 180: 1320- 1323.

Singh A,Dantas ZN, Stone SC and Asch RH: Presence of thyroid antibodies in early reproductive failure: biochemical versus clinical pregnancies. Fertil Steril 1995;63:277-81.

Spencer CA, Takeuchi M and Kazarosyan M: Current status and performance goals for serum thyroglobulin assay. Clin Chem 1996; 42: 164-173.

Stagnaro-Green A, Roman SH, Cohen RH, EI-Harazy E, Alvary-Marfany M, Davies TF. Detection of at-risk pregnancy by means of a highly sensitive assays for thyroid autoan tibodies. JAMA 1990;264:1422-1425.

Stagnaro-Green A, Roman SH, Cohen RH, El-Harazy E, Wallerstein S, Davies TF. A prospective study of lymphocyte-initiated immune-suppression in normal pregnancy: evidence of a T-cell etiology for post partum thyroid dysfunction. J Clin Endocrinol Metab 1992:74:645-653.

Stagno S: Cytomegalovirus. In: Remington JS, Klein JO, eds. Infectious diseases of the fetus and newborn infant. Philadelphia: WB Saunders Co,1995:312-45.

Stirrat GM. Recurrent miscarriage II: clinical associations,causes, and management. Lancet 1990;336:728-33.

Yoto $\mathbf{Y}$, Kudoh T, Haseyama $\mathrm{K}$ and Suzuki N: Large -scale screening for human parvovirus B19 DNA in clinical specimenes by dot blot hyberidization and polymerase chain reaction. $\mathrm{J}$ Med. Virol, 1995; 47: 438-441.

Zakryewska K, Azzi A, Patou G and Morfini M: Human parvovirus B19 in clotting concentrates: B19 DNA detection by the nested polymerase chain reaction. Brit. J. Hematol. 1992, 81: 407- 412.

Zerbini M, Musiani M, Gentilomi G, Venturoli S, Gallmella $G$ and Morandi 
$\mathrm{R}$ : Comparative evaluation of virological and serological methods in prenatal diagnosis of parvovirus B19 fetal hydrops. J. Clin. Microbiol. 1996; 34: $603-608$.

\title{
الملخص العربي \\ فيروس بارفو بي19وفيروس السيتوميجالو وحدوث المناعة الذاتية للغدة الدرقية

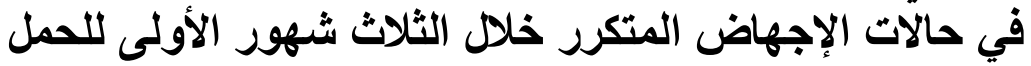

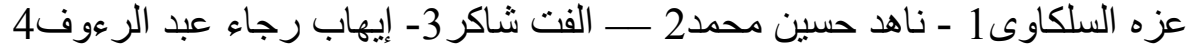

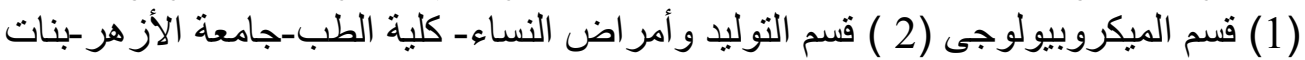 \\ (3) قسم الكيمياء الحيوية الطيبة- كلية الطب جامعة القاهرة-و(4) قسم الور اثنة البشرية ـ المركز القومي اللبحوث
}

يعد الإجهاض المتكرر مشكلة هامة فهنالك أسباب عديدة له وكذلك سبل علاج مختلفة ولكن لم تثبت دلائل

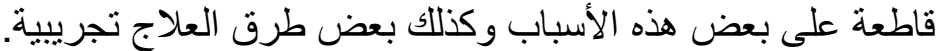

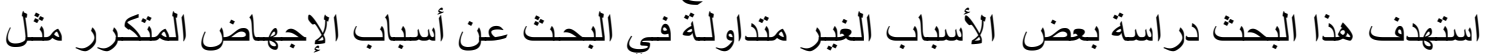

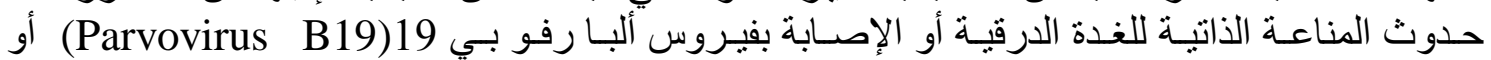

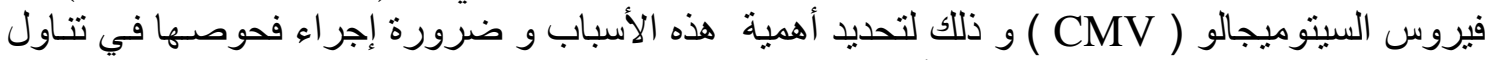
حالات الإجهاض المتكرر غير معلوم الأسباب.

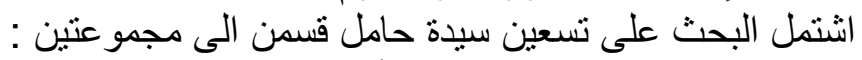

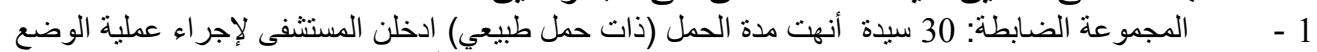

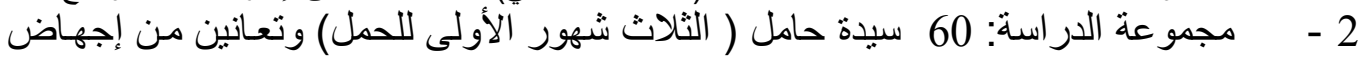

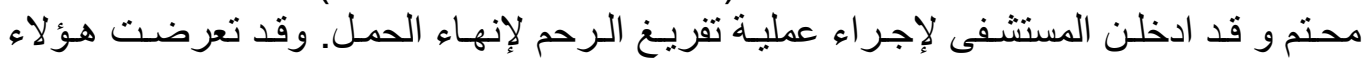

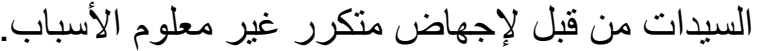
نم اخذ عينات دم وفصل الإفير السيرم لعمل التحاليل الآتية:

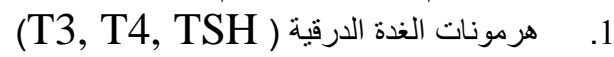

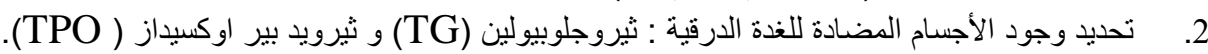
3.

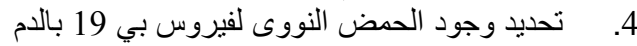

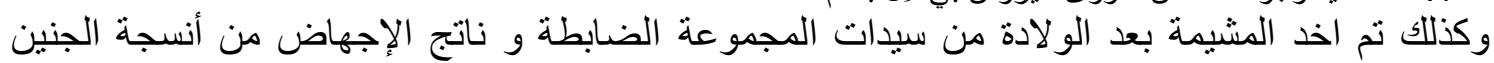

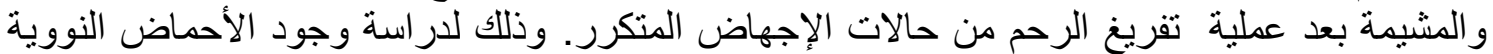
لفيروس ألبا رفو بي 19 أو فيروس السيتوميجة الريجالو في هذه الأنسجة باستخدام طريقة الختبار سلسلة

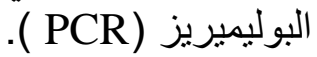
وكانت نتائج البحث كالآتي : دراسة وجود الأحماض النووية للفيروسات أثنتت إصابة تلث حالات الثات

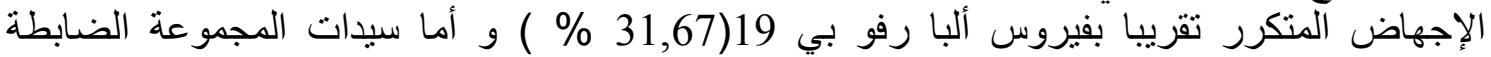

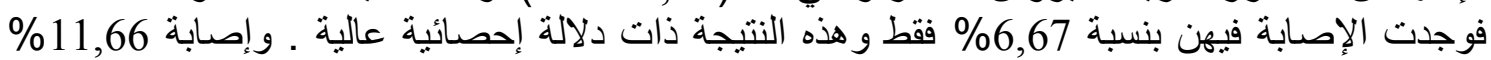

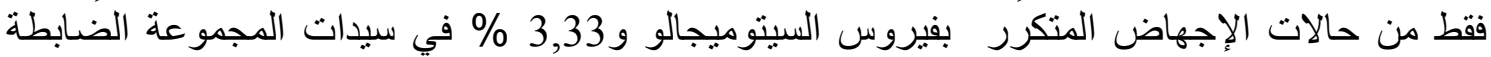

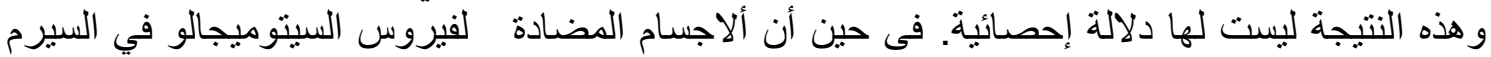

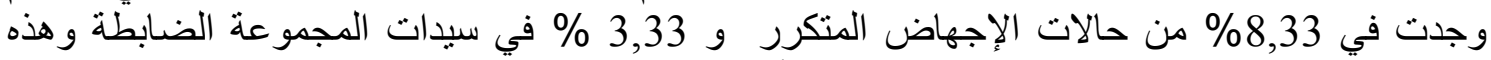

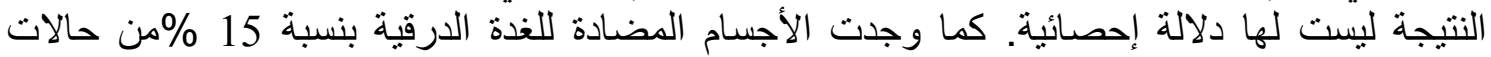
الإجهاض المتكرر و 6,67 \% من سيدات المجموعة الضابطة وهذه النتيجة ليست لها دلالة إحصائية.

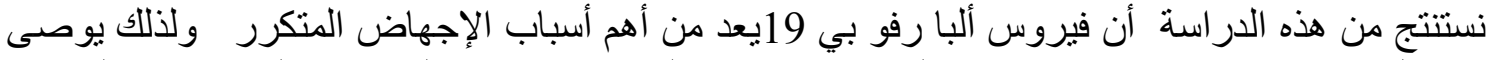

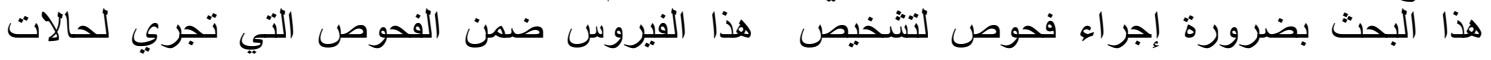

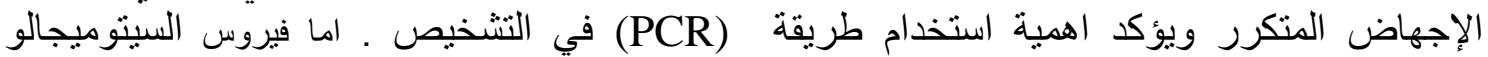

و الأجسام المضادة للغدة الدرقية فيمكن اختبار ها فى حالات الإجهاض المتكرر غير معروف السبب . 